\title{
Concave Design for High-Moisture Corn Ear Threshing
}

\author{
Dainius STEPONAVIČIUS*, Edvinas PUŽAUSKAS**, Liudvikas ŠPOKAS***, \\ Eglè JOTAUTIENE் $* * * *$, Aurelija KEMZŪRAITE் $* * * * *$, Sigitas PETKEVIČIUS $* * * * * *$ \\ *Institute of Agricultural Engineering and Safety, Aleksandras Stulginskis University, Studentu 15A, 53362 Akademija, \\ Kaunas distr., Lithuania, E-mail: Dainius.Steponavicius@asu.lt \\ **Institute of Agricultural Engineering and Safety, Aleksandras Stulginskis University, Studentu 15A, 53362 Akademija, \\ Kaunas distr., Lithuania, E-mail: e.puzauskas@hotmail.com \\ ***Institute of Agricultural Engineering and Safety, Aleksandras Stulginskis University, Studentu 15A, 53362 Akademija, \\ Kaunas distr., Lithuania, E-mail: Liudas.Spokas@asu.lt \\ ****Institute of Agricultural Engineering and Safety, Aleksandras Stulginskis University, Studentu 15A, 53362 Akademija, \\ Kaunas distr., Lithuania, E-mail: Egle.Jotautiene@asu.lt \\ *****Institute of Agricultural Engineering and Safety, Aleksandras Stulginskis University, Studentu 15A, 53362 \\ Akademija, Kaunas distr., Lithuania, E-mail: Aurelija.Kemzuraite@asu.lt \\ ******Institute of Agricultural Engineering and Safety, Aleksandras Stulginskis University, Studentu 15A, 53362 \\ Akademija, Kaunas distr., Lithuania, E-mail: Sigitas.Petkevicius@asu.lt
}

crossref $h$ ttp://dx.doi.org/10.5755/j01.mech.24.1.18345

\section{Introduction}

The varieties of corn grown in recent times can be classified into two groups: corn for silage and corn for grain. In the first case, the entire corn crop is harvested with forage harvesters, whereas in the second case (with combine harvesters), cobs are pulled off the stalks by strippers attached to the header and then threshed by a tangential or axial threshing device [1]. With the threshing device being the core unit of a combine harvester, its performance directly influences the quality of corn harvesting [1]. Although the axial threshing device has a greater throughput compared with a tangential device [2,3] and is characterised by less damage to the grain [4], combine harvesters with a tangential threshing device tend to be common in more humid climate zones [3]. Moreover, a tangential threshing device, which is used in conventional and hybrid combine concepts, is known for its high installation space and energy efficiency [5].

In the U.S. and Western European countries, corn for grain production is traditionally harvested when the grain moisture content reaches approximately $18-25 \%$ [6]; hence, combine harvesters have been designed to harvest corn of such a moisture content. High moisture corn ear processing operations have not been extensively explored. In countries with a more humid climate, including the Baltic States, corn ears are harvested in the second half of October and sometimes as late as after the first frost, when grain dry matter content is lower than 65\% [7]. Although corn grain reaches physiological maturity at $35 \%$ moisture $[6,8]$, corn plants cultivated for grain production should be harvested when the grain moisture content does not exceed $28 \%$ [9]. At crop moisture of over $28 \%$ w. b., grain becomes softer and can be squeezed very easily, leading to greater grain damage [2]. Mechanical damage to grain at harvest is mostly caused by field threshing, which is largely due to a high moisture content. Studies have shown that minimum grain damage during corn ear threshing is registered at moisture contents between $20 \%$ and $22 \%$ [10].

Key evaluation factors of combine harvester operations during corn ear harvesting include grain loss and grain damage [11]. The following harvest losses at optimum combine adjustment are generally considered acceptable: header ear loss $-1.0 \%$, header grain loss $-0.4 \%$, cylinder or threshing loss $-0.3 \%$ and cleaning shoe loss $-0.1 \%$ [12]. Moreover, less than $20 \%$ of the threshed grains should be thrown to the straw walker [7]. Reducing ground speed helps reduce grain loss by allowing more time for separation of grain and residue [13]. Although combine manufacturers continue to make combine adjustments that are easier to perform, operators must make proper adjustments to ensure that total grain losses are below $5 \%$. In practice, the time spent evaluating and optimising harvest equipment loss efficiency can make a difference to profit margins [12].

Covering clearances between adjacent cylinder rasp bars prevent corn ears from entering the cylinder and plant particles and soil from accumulating in the cylinder, thus avoiding any cylinder imbalance. It has been asserted that when threshing high moisture corn, concave inserts can be used to avoid losses from reduced threshing [12], to help reduce loads on the cleaning shoe and to increase threshing performance in cases of high moisture corn that is hard to thresh. Inserts also prevent broken cob pieces with unthreshed grains from falling through the concave onto the cleaning area. On the other hand, inserts reduce the active separation area of the concave.

High moisture content corn is more susceptible to mechanical damage from machinery during harvest [2]. Ferreira et al. [8] claimed that a progressive increase in mechanical damage to grains (caused by the rotation of the threshing cylinder) as moisture content increases at harvest contributes to a decrease in grain physiological potential and an increase in the occurrence of fungi during grain storage. Majority of the research on threshing has demonstrated that high cylinder speed is the main factor causing grain damage $[13,14]$. Other combine harvester parameters such as cylinder-concave clearance and type of cylinder bar seem to affect grain damage only slightly [15]. Grain detachment from the corn cob starts at a cylinder rasp bar speed of $7 \mathrm{~m} \mathrm{~s}^{-1}$, and grain damage occurs as soon as the rasp bars reach a speed of $14 \mathrm{~m} \mathrm{~s}^{-1}$ [16]. The feed into the threshing device is 
formed of non-uniform corn ears of different moisture contents, and the cylinder rasp bar speed should be adjusted to provide proper threshing of more humid corn ears. Grain damage has been found to increase from $3.9 \%$ to $6.1 \%$ at a $20.3 \mathrm{~kg} \mathrm{~s}^{-1}$ corn ear feed rate into the threshing device and variation of the rasp bar speed from 16.9 to $21.4 \mathrm{~m} \mathrm{~s}^{-1}$ [4]. The damage to grains subjected to a dynamic loading depends on their elasticity modulus [17]. Moreover, deformation of corn ear parts and grain detachment from cobs have been found to depend on the elasticity modulus of the corn ear grains and cobs [18]. It has been claimed that rational cylinder rasp bar speeds range between 10 and $20 \mathrm{~m} \mathrm{~s}^{-1}$ [3], and that grain damage may be reduced by changing the clearance between the cylinder rasp bars and the concave crossbars [19].

The efficiency of the threshing process has been found to depend on the geometrical shape of the concave crossbars [18]. As part of the preparation of combine harvesters for corn ear harvesting, the threshing device concave is replaced with a special concave with rounded crossbars [4]. The clearances between the crossbars may vary from 45 to $80 \mathrm{~mm}$, depending on the concave's manufacturer. During the threshing process, concave crossbars serve as supports for corn ears subjected to impact by rasp bars, thus reducing the rate at which corn ears move over the concave surface and increasing threshing efficiency. Corn ear diameter tends to decrease during threshing, and the clearance between the cylinder rasp bars and concave crossbars is also expected to decrease along the concave length $[15,20]$. The recommended clearance between the cylinder rasp bars and the first concave crossbar is about $10 \mathrm{~mm}$ smaller than the average ear diameter, whereas at the last concave crossbar, it is equal to, or slightly smaller than, the average cob diameter [7]. In view of the corn ear biometrics, clearance between the cylinder rasp bars and concave crossbar at the end of the concave is recommended to be $15 \mathrm{~mm}$ smaller than the clearance at the beginning of the concave [21]. Some researchers have suggested that a rational concave clearance is $35-40 \mathrm{~mm}$ at the beginning and $18-20 \mathrm{~mm}$ at the end [22], while some have suggested $25-30 \mathrm{~mm}$ at the beginning and $15-20 \mathrm{~mm}$ at the end $[3,14]$. A number of researchers have analysed corn ear threshing using tangential threshing devices of different designs, process parameters, ear feed rates and biometrics, resulting in considerably different clearances being recommended for the beginning and end of the concave.

Grain damage can possibly be reduced by redesigning the threshing mechanism, which includes both the cylinder and the concave, so that the shelled grains can leave the threshing crescent immediately after shelling [23]. Previous research has demonstrated that an increase in concave rod spacing tends to reduce the threshing unit loss [24]. This concurs with the research by Norris and Wall [25] who found that when the concave rod spacing was increased from 21 to $30 \mathrm{~mm}$, shelled grains pass through the concave with more ease, leading to a $24 \%$ decrease in grain damage and a $38 \%$ increase in grain separation efficiency. The concave surface line of certain combine harvesters corresponds to a circular arc. As a result, the reduction of clearance between the cylinder rasp bars and the concave crossbars is non-uniform along the concave length [20, 26]. During grain harvesting, the clearance between the cylinder rasp bars and concave is subject to variation within a narrow range [3], and non-uniform variation of this clearance insignificantly affects the qualitative performance indicators of threshing. In corn ear harvesting, the clearance is about three-fold larger than that applied in grain harvesting. A designed concave characterised by its surface line approximating Archimedes' spiral would lead to more uniform clearance variation $[20,26]$. Nonetheless, its influence on qualitative corn ear threshing indicators has not yet been studied. A non-uniform variation in the clearance between the cylinder rasp bars and concave crossbars could lead to variation in the ear movement rate and the number of their interactions with rasp bars; in turn, this could cause grain damage and impact grain separation in the concave.

This work aims to determine the influence of concave shape and crossbar layout on (i) the behaviour of humid corn ears during threshing and (ii) the qualitative performance indicators.

\section{Materials and methods}

\subsection{Biometric indicators}

Thirty corn ears were random selected by triplicate sampling of a stock of handpicked corn ears (Rodni variety). Each corn ear was weighed separately, and husk leaves were removed from the ears and weighed. The lengths of each corn ear and the diameter variation along the ear length were determined, and the number of grains in vertical rows and horizontal rings were counted. Following grain separation from each corn cob, the grains and the cob were weighted separately. Cob length and diameter variation along its length were measured. Arithmetic averages and confidence intervals were calculated for each ear sample. Ear grains, cobs and husk leaves were oven dried at $100^{\circ} \mathrm{C}$ for 72 hours for moisture content determination.

\subsection{Test bench}

Experimental trials were conducted in the laboratory by threshing high moisture corn ears (grain moisture content of $36.16 \% \pm 1.83 \%$ ). Ears were fed by belt conveyor 1 (Fig. 1) into a threshing device consisting of 10 rasp bars, cylinder 2 (800 mm diameter and $1500 \mathrm{~mm}$ wide) and concave 3 . The test bench was driven by a $30 \mathrm{~kW}$ electric motor. The threshing cylinder rotation frequency was held constant $\left(350 \mathrm{~min}^{-1}\right)$ by a voltage frequency converter Delta VFD-C2000 SERIES and a cylinder gear variator.

This study involved comparative experimental trials of two concaves with different shapes. The surface line of the control concave (conventional design) corresponds to a portion of a circular arc (Figs. 2, b, d and f), whereas the experimental concave corresponds to a portion of Archimedes' spiral (Figs. 2, a, c and e). Both concaves provide the option of adjusting the clearance between adjacent crossbars (45.0, 62.5 and $80.0 \mathrm{~mm})$; in turn, the number of crossbars and the active separation area can also be adjusted (Table 1). Half of the crossbars in the first section of each concave were rectangular ( $8 \mathrm{~mm}$ wide and $9 \mathrm{~mm}$ high above the concave rods); the remaining crossbars had similar dimensions but were rounded ( $r=4 \mathrm{~mm}$ ). At the beginning of both concaves, a $36.0 \mathrm{~mm}$ clearance was set between the first crossbar and the cylinder rasp bar; this clearance was $22.0 \mathrm{~mm}$ at the end. The measurement of clearances between the cylinder rasp bar and control concave crossbars showed that the 
clearance increased from 36.0 to $48.1 \mathrm{~mm}$ up to the ninth crossbar, was $44.9 \mathrm{~mm}$ at the twelfth crossbar and was
$22.0 \mathrm{~mm}$ at the end of the concave, with the clearance between adjacent crossbars being $45.0 \mathrm{~mm}$.

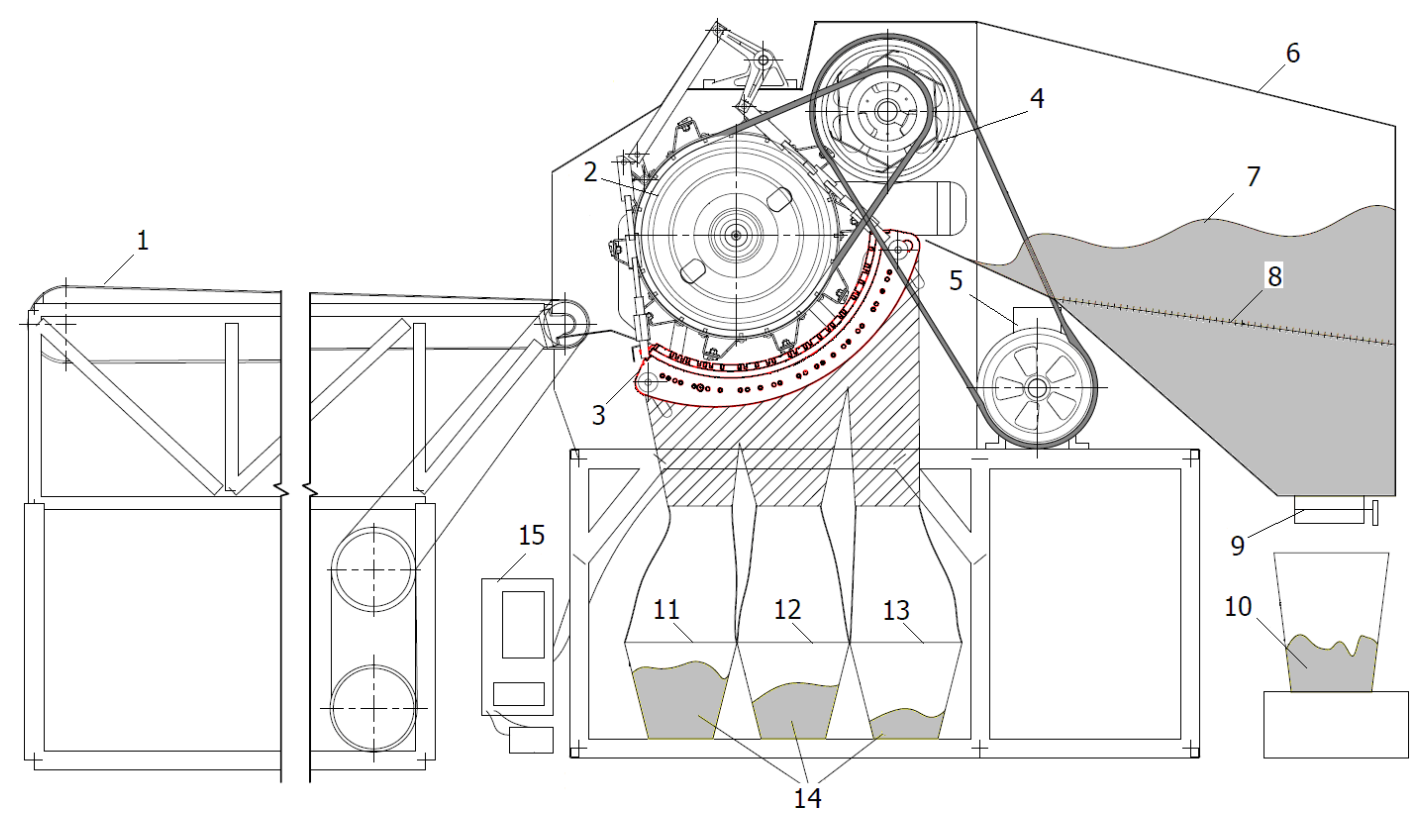

Fig. 1 Test bench for corn ear threshing [18]: 1 - belt conveyor; 2 - threshing cylinder; 3 - control or experimental concave; 4 -beater cylinder; 5 -electric motor; 6 -threshed matter container; 7 -threshed matter; 8 -sieve; 9 -valve; 10 - grain; 11-13 - containers; 14 - grain with impurities; 15 - voltage frequency converter

For the experimental concave, the clearance decreased consistently along the concave arc length and was $24.6 \mathrm{~mm}$ at the ninth concave crossbar, $22.7 \mathrm{~mm}$ at the twelfth crossbar and $22.0 \mathrm{~mm}$ at the end of concave. It should be noted that the experimental concave arc was $65.00 \mathrm{~mm}$ shorter; therefore, the experimental concave had one less crossbar than the control concave. The wrap angle of both concaves around the cylinder was the same at $123^{\circ}$, with a clearance equal to $36-22 \mathrm{~mm}$. The wrap angle of the concave around the cylinder decreased when the clearance increased. The clearance between the cylinder and experimental concave may also be adjusted in view of the ear diameter. In this case, uniform variation of the concave would not be observed; however, the deviation would not be significant.

Concave parameters

\begin{tabular}{|c|c|c|c|c|c|c|c|c|c|}
\hline \multicolumn{2}{|c|}{$\begin{array}{c}\text { Concave arc } \\
\text { shape }\end{array}$} & $\begin{array}{l}\text { Total } \\
\text { con- } \\
\text { cave } \\
\text { area } \\
A, \mathrm{~m}^{2}\end{array}$ & $\begin{array}{c}\text { Active } \\
\text { separa- } \\
\text { tion } \\
\text { area } A_{s}, \\
\%\end{array}$ & \multirow{2}{*}{$\begin{array}{l}\text { Con- } \\
\text { cave arc } \\
\text { length } \\
L, \mathrm{~m}\end{array}$} & \multirow{2}{*}{$\begin{array}{c}\text { Con- } \\
\text { cave arc } \\
\text { angle } \alpha, \\
\circ\end{array}$} & \multirow[t]{2}{*}{$\begin{array}{l}\text { Wrap angle of } \\
\text { concave around } \\
\text { cylinder } \beta,{ }^{\circ}\end{array}$} & $\begin{array}{l}\text { Clearances } \\
\text { between } \\
\text { crossbars } l \text {, } \\
\text { mm }\end{array}$ & $\begin{array}{l}\text { Num- } \\
\text { ber of } \\
\text { cross- } \\
\text { bars }\end{array}$ & \multirow{2}{*}{$\begin{array}{c}\text { Number of } \\
\text { rounded } \\
\text { crossbars in } \\
\text { the second } \\
\text { section of } \\
\text { concave } \\
8\end{array}$} \\
\hline Experi- & Fig. 2, a & & 56.7 & & & & 45.0 & 18 & \\
\hline mental & Fig. 2, c & 1.34 & 59.1 & 0.910 & 120 & \multirow{5}{*}{123} & 62.5 & 14 & 7 \\
\hline & Fig. 2, e & & 60.3 & & & & 80.0 & 12 & 6 \\
\hline Con- & Fig. 2, b & & 56.5 & & & & 45.0 & 19 & 9 \\
\hline trol & Fig. 2, d & 1.39 & 58.8 & 0.975 & 130 & & 62.5 & 15 & 7 \\
\hline & Fig. $2, \mathrm{f}$ & & 60.0 & & & & 80.0 & 13 & 6 \\
\hline
\end{tabular}

\subsection{Analysis of corn ear movement over the concave sur face}

Corn ear behaviour in the clearance between the cylinder and the concave was recorded by high-speed video camera (Photron Fastcam 1024PCI; Photron, Japan) at a frame rate of $2000 \mathrm{f} \mathrm{s}^{-1}$. Corn ears were placed one by one on a special tray bottom and then rolled parallel to the threshing cylinder shaft into the clearance between the cylinder rasp bars and the first concave crossbar. The time to the start of ear movement over the surface of the first concave crossbar after contact between the ear and the cylinder rasp bar, and the time to the fall of the threshed ear off the concave, was recorded. Analysis of the video material demonstrated the variation in ear position during its movement in the clearance between the cylinder rasp bars and the concave, as well as the duration of the movement, the average movement rate and the number of impacts between the rasp bars and the ear. 

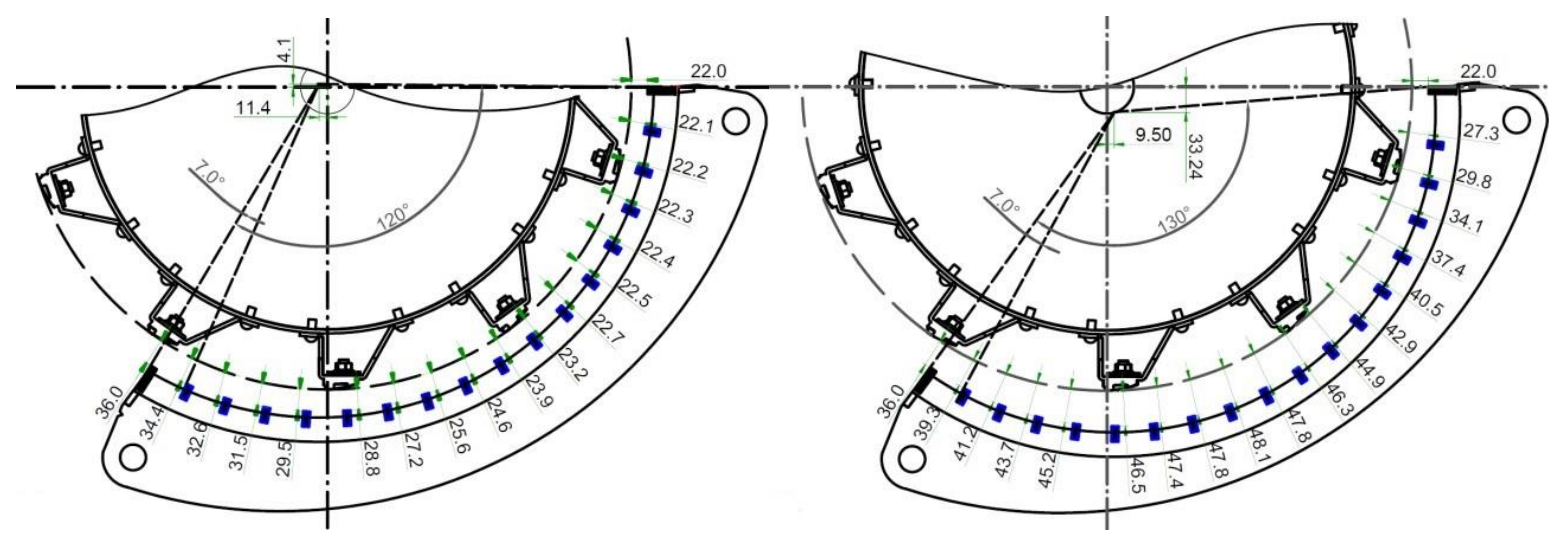

a

b

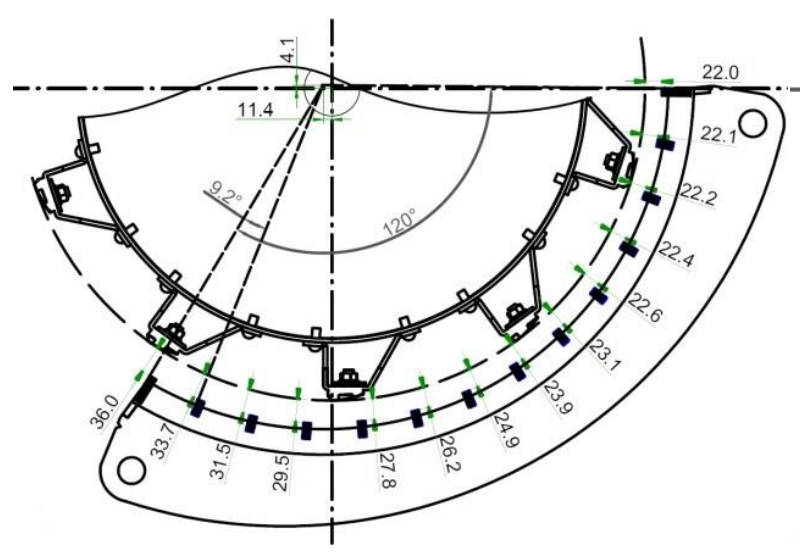

c

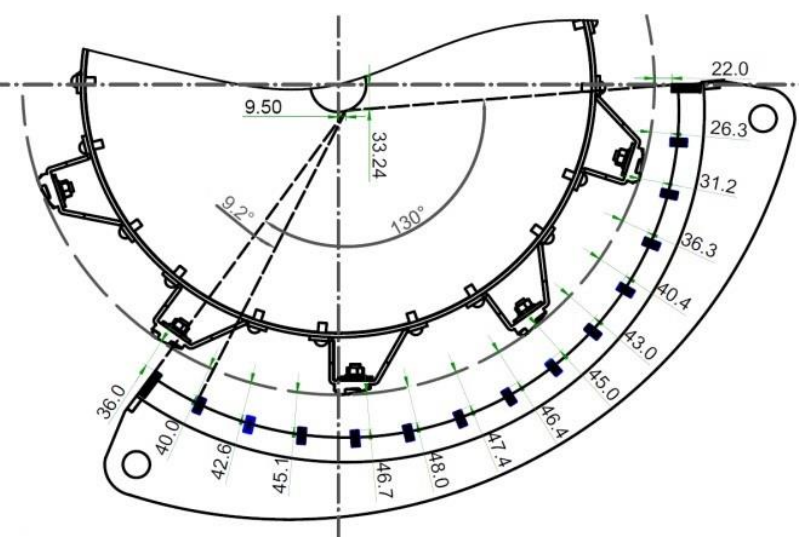

d
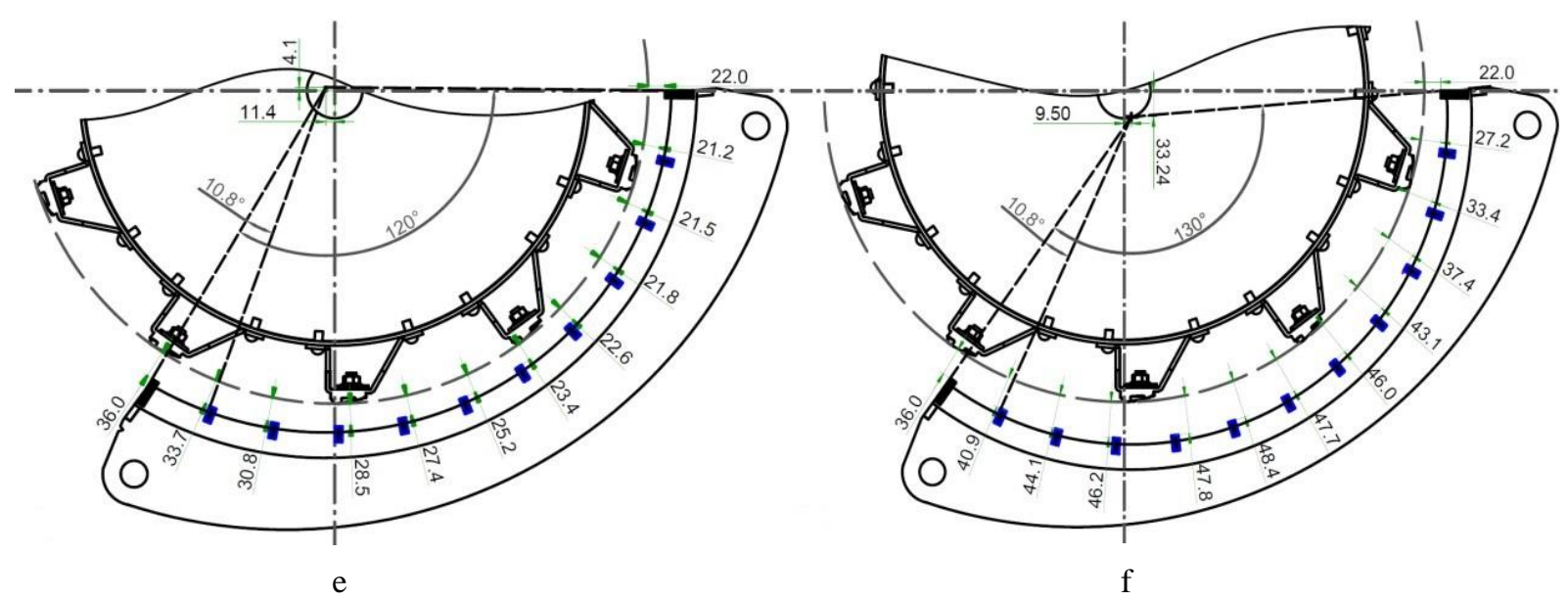

Fig. 2 Shapes of concaves used for the trials: a, c, e - experimental concave; b, d, f - control concave (Table 1)

2.4. Amount of ears fed into the threshing device and performance indicators of the threshing process

Corn ears were fed into the threshing device at a speed of $1 \mathrm{~m} \mathrm{~s}^{-1}$ by the $10 \mathrm{~m}$ long belt conveyor (Fig. 1). The total mass fed into the threshing device was varied from 5.6 to $20.6 \mathrm{~kg} \mathrm{~s}^{-1}$ by spreading different masses of ears on a $7 \mathrm{~m}$ length of the belt conveyor. Three sections characterised by equal areas were identified as the concave of the threshing device (Fig. 1). During corn ear threshing, threshed grains that passed through the concave sections entered containers 11,12 and 13 . The threshed grains were weighed using an electronic scale (CAS DB-1H;CAS, South Korea). The portion of coarse impurities in the grain was determined by sieving the threshed grain through a $5 \mathrm{~mm}$ mesh. Impurities remaining on the sieve and the grain that had passed through the sieve were weighed separately; their amounts demonstrated grain separation through the concave. Threshed matter (corn cobs, leaves and threshed grain not separated through the concave) 7 that dropped off the concave end due to the threshing cylinder rasp bars and beater cylinder 4 blades was collected in a separate container 6 . Grains that passed through the sieve 8 in the threshed matter container and collected in the container were weighed separately. The masses of these grains allowed calculation of the grain separation loss in the threshing device. Grain loss at threshing was calculated by the detachment of non-threshed grain from each corn cob and its weighing by an electronic scale Kern CM 320-1N (Kern, Germany). Five $100 \mathrm{~g}$ samples of grain that had fallen through each concave section were taken. Mechanically damaged grains were separated from each sample and weighed. The average percentage of damaged grains was calculated. 


\subsection{Power consumption}

The active power required for rotation of the threshing cylinder was measured simultaneously using two electric power system analysis devices: ME-MI2492 (Metrel, Slovenia) and Almemo 2890-9 (Ahlborn, Germany) [18].

\subsection{Statistical analysis}

The experiments were carried out with three or four replicates. Regression and correlation analyses were used to evaluate the results. A 0.05 probability level was used as the criterion for tests of significance throughout the data analysis.

\section{Results and discussion}

Key quality indicators of the corn ear threshing process are grain damage, grain threshing loss and grain loss from separation through the concave. These indicators de- pend on design and process parameters of the threshing device, biometric indicators of the corn ears and the amount of ears fed into the threshing device $[11,12]$.

\subsection{Biometric indicators of corn ears}

During threshing, the average grain moisture content of the corn ears (Table 2) was $36.16 \% \pm 1.83 \%$, while those of the cobs and husk leaves were $61.94 \% \pm 7.52 \%$ and $64.63 \% \pm 6.83 \%$, respectively.

The grain moisture content variation along the corn ear length was given by:

$$
w=-0.0011 n^{2}-0.147 n+37.76 ; R^{2}=0.94,
$$

where: $n$ is the number of grain rows along the ear length (Table 2).

Grain with the highest moisture content was found to concentrate at the ear end. This is because the cob is attached to the stalk at the node and the moisture content of the stalk was about $20 \%$ higher than that of the cob. Moreover, its diameter along the ear length of $0-84 \mathrm{~mm}$ and its 1000 grain mass are the largest.

Table 2

Biometric indicators of corn ears

\begin{tabular}{|l|c|c|}
\hline \multicolumn{1}{|c|}{ Indicator } & Unit of measurement & $\begin{array}{c}\text { Average value ( } \pm \text { confidence in- } \\
\text { terval values at 95\% probability) }\end{array}$ \\
\hline Corn ear mass & $\mathrm{g}$ & $225.13 \pm 12.36$ \\
\hline Maximum corn ear diameter & $\mathrm{mm}$ & $45.89 \pm 0.79$ \\
\hline Corn ear length & $\mathrm{mm}$ & $173.56 \pm 3.55$ \\
\hline Number of grains & $\mathrm{g}$ & $476.70 \pm 18.36$ \\
\hline Grain mass (14\% moisture content) & rows & $120.00 \pm 8.08$ \\
\hline Number of vertical rows in the corn ear & rows & $13.77 \pm 0.41$ \\
\hline Number of horizontal rows in the corn ear & $\mathrm{mm}$ & $35.47 \pm 0.98$ \\
\hline Maximum cob diameter & $\mathrm{g}$ & $28.36 \pm 0.53$ \\
\hline Cob mass (18\% moisture content) & $\mathrm{g}$ & $19.89 \pm 13.10$ \\
\hline 1000 grain mass (14\% moisture content) & $245.03 \pm 8.73$ \\
\hline
\end{tabular}

Researchers have claimed that the correct cylinder speed and concave clearance adjustment may reduce threshing losses to $0.3 \%$ or less [12]. Grain losses during threshing should be reduced by altering concave clearance since the impact of the concave on grain damage is low compared with an increase in cylinder peripheral velocity [22]. In view of the different diameters of the corn ears fed into the combine harvester, diameter variation along the corn ear length was determined to evaluate the effect of the clearance between the cylinder rasp bars and the concave (Fig. 3).

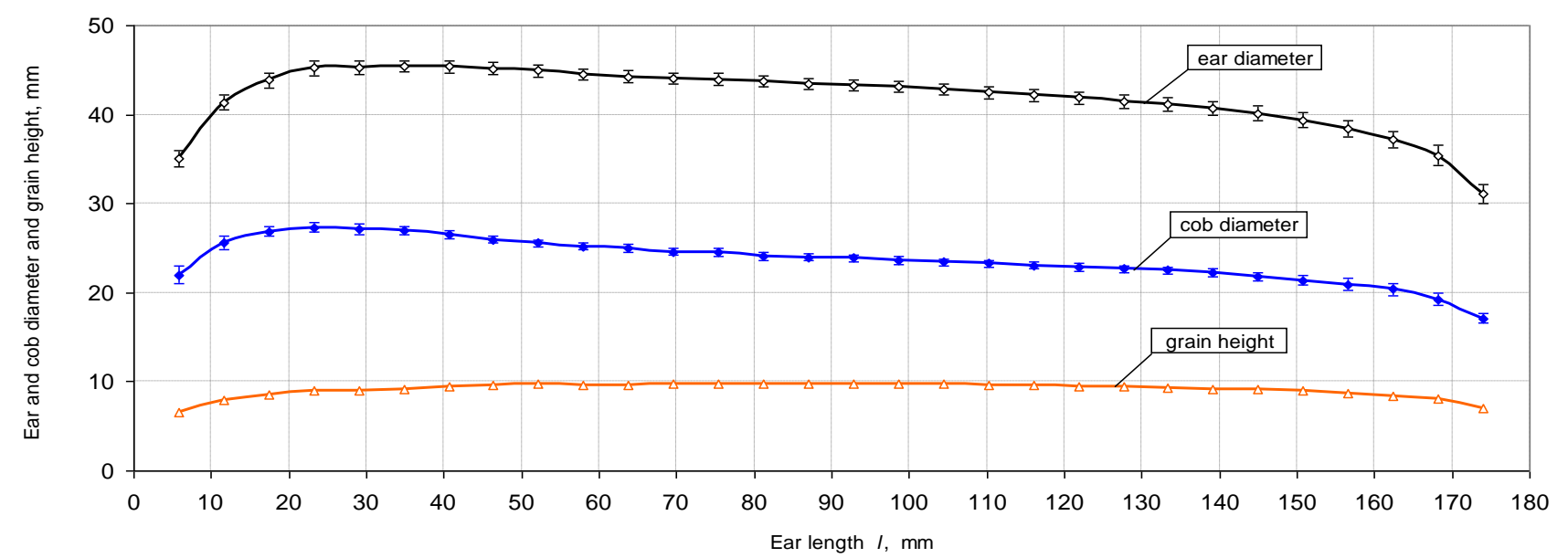

Fig. 3 Variations in corn ear diameter, cob diameter and grain height along the ear length 
The maximum diameter of corn ears with 14 vertical grain rows was $45.89 \pm 0.79 \mathrm{~mm}$, while the average grain height was $9.8 \pm 0.2 \mathrm{~mm}$. In view of the diameter variation along the corn ear length, and based on the recommendations by other authors [7], a $36 \mathrm{~mm}$ clearance between the first concave crossbar and cylinder rasp bars and a $22 \mathrm{~mm}$ clearance at the end of concave, were set during the trials. The clearance between the cylinder rasp bar and the first concave crossbar (36 mm) was determined as follows: maximum corn ear diameter $(45.89 \pm 0.79 \mathrm{~mm})$ minus the average grain height $(9.8 \pm 0.2 \mathrm{~mm})$. The clearance between the cylinder rasp bar and the last concave crossbar (22 $\mathrm{mm})$ was determined by adding half of the average grain height (4.9 $\pm 0.1 \mathrm{~mm})$ to the smallest cob diameter $(17.15 \pm 0.22 \mathrm{~mm})$.

\subsection{Corn ear movement and behaviour in the clearance} between cylinder rasp bars and concave

Corn ear behaviour in the clearance between the cylinder rasp bars and the concave crossbars depends on the diameter variation along its length and its position with respect to the first concave crossbar, whereas grain detachment from the cob depends on the strength of the grain bond to the cob $[7,10]$. Concave surface line variation equations were developed in view of the ear dimensions and were based on the assumption that the clearance between the cylinder rasp bars and concave crossbars at the beginning and end of the threshing device is $36 \mathrm{~mm}$ and $22 \mathrm{~mm}$, respectively, for the both control and experimental concaves. The analysis of threshing devices is possible with the mathematical description of the curve characteristic over the separation length [5]. In this study, an $800 \mathrm{~mm}$ diameter threshing cylinder was used for the trials of both concaves. Its circumference equation with respect to the centre $\mathrm{O}\left(x_{o}, y_{o}\right)$ in the Cartesian coordinate system was generated, yielding the following coordinates (Fig. 4):

$$
\left\{\begin{array}{l}
x=x_{o}+r \cos \varphi \\
y=y_{o}+r \sin \varphi
\end{array},\right.
$$

where: $r$ is the cylinder radius set at $r=400 \mathrm{~mm}$ and $\varphi$ is the cylinder circumference line angle at a chosen point that varies from 0 to $2 \pi$.

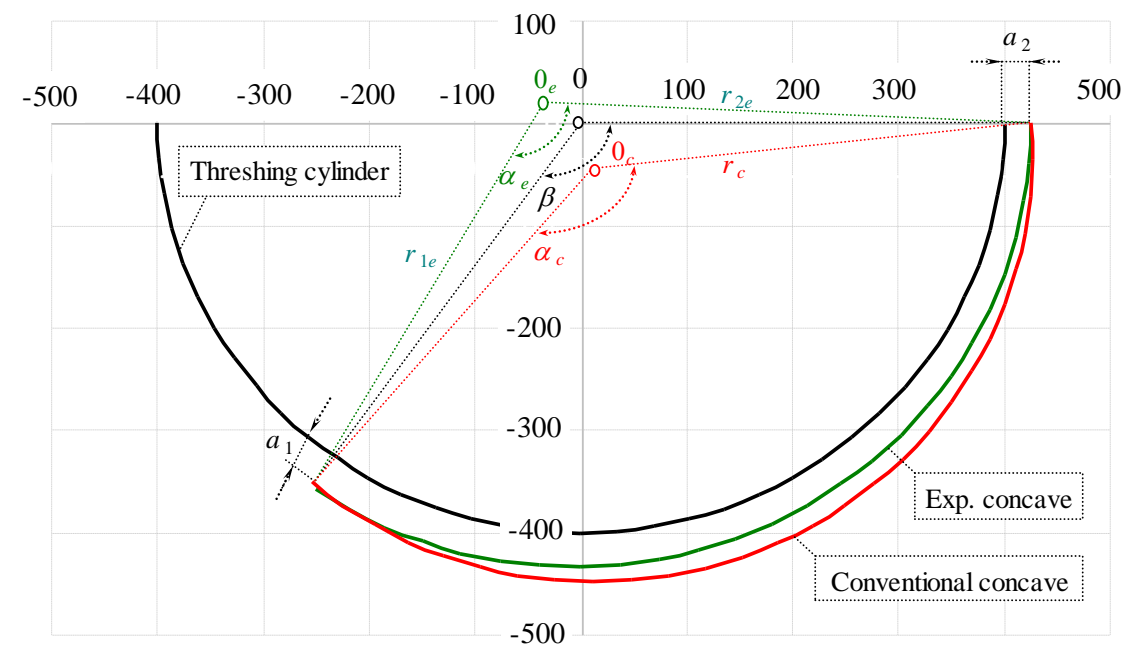

Fig. 4 Surface shapes of the experimental and control concaves in the Cartesian coordinate system: $\mathrm{O}\left(x_{o}, y_{o}\right)-$ cylinder centre with the coordinates, $\mathrm{O}_{c}\left(x_{o c}, y_{o c}\right) ; \mathrm{O}_{e}\left(x_{o e}, y_{o e}\right)$ - convex surface centres of the control and experimental concaves with coordinates; $r_{1 \mathrm{e}}, r_{2 \mathrm{e}}$ - distances of experimental concave from the centre $\mathrm{O}_{e}(-11.4$ and $4.1 \mathrm{~mm})$ at the beginning and end of the threshing device; $r_{c}$-distance of control concave from the centre $\mathrm{O}_{c}(9.50$ and $-33.24 \mathrm{~mm}) ; a_{1}-$ clearance between the cylinder and concave in the front part of the threshing device, $a_{1}=36 \mathrm{~mm}$; $a_{2}$-clearance between the cylinder and concave in the rear part of the threshing device, $a_{2}=22 \mathrm{~mm} ; \alpha_{e}$ - arc angle of the experimental concave, $\alpha_{e}=120^{\circ} ; \alpha_{c}-\operatorname{arc}$ angle of the control concave, $\alpha_{c}=130^{\circ} ; \beta$ - wrap angle of concave around the cylinder, $\beta=123^{\circ}$

The control concave wrap line equation relative to the cylinder centre $\mathrm{O}\left(x_{o}, y_{o}\right)$ was generated, yielding the following coordinates for the control concave:

$$
\left\{\begin{array}{l}
x_{c}=x_{o c}+r \cos \beta_{n} \\
y_{c}=y_{o c}+r \sin \beta_{n}
\end{array},\right.
$$

where: $x_{o c}$ and $y_{o c}$ are the coordinates of the arc centre of the control concave relative to the cylinder centre $\mathrm{O}\left(x_{o}, y_{o}\right)$ set at values $x_{o c}=9.50 \mathrm{~mm}$ and $y_{o c}=-33.24 \mathrm{~mm}$ and $\beta_{n}$ is the wrap angle of concave around the cylinder at a chosen point that varies from $236^{\circ}$ to $360^{\circ}$.

The wrap line equation for the experimental concave relative to the cylinder centre $\mathrm{O}\left(x_{0}, y_{0}\right)$ was generated, yielding the following coordinates for the experimental concave:

$$
\left\{\begin{array}{l}
x_{e}=\left(r+a_{1}+a_{2}-\left(\left(\frac{a_{1}-a_{2}}{\beta}\right) \beta_{n}\right)\right) \cos \beta_{n} \\
y_{e}=\left(r+a_{1}+a_{2}-\left(\left(\frac{a_{1}-a_{2}}{\beta}\right) \beta_{n}\right)\right) \sin \beta_{n}
\end{array},\right.
$$

where: $a_{1}$ is the clearance between the cylinder and concave at the beginning of the threshing device set at $a_{1}=36 \mathrm{~mm}$, $a_{2}$ is the clearance between the cylinder and concave at the end of the threshing device set at $a_{2}=22 \mathrm{~mm}, \beta$ is wrap angle of concave around the cylinder set at $\beta=123^{\circ}$ and $\beta_{n}$ is 
the wrap angle of concave around the cylinder at a chosen point.

Variation in the clearance between the cylinder rasp bars and concave crossbars along the concave length is presented in Fig. 5.

A linear reduction in the clearance between the cylinder rasp bars and concave crossbars was registered from the beginning of the concave to the middle of the experimental concave. Starting with $\beta=75^{\circ}$, i.e., the 12 th crossbar, the variation in the clearance is insignificant. For the threshing device with the control concave, clearance $a$ increased to $48 \mathrm{~mm}$ up to $\beta=45^{\circ}$, i.e., the 9 th crossbar. Subsequently, there was a gradual reduction. In general, variation in clearance $a$ along the concave length may be defined as a convex parabola. This increase in clearance $a$ is unreasonable during threshing as a corn ear with an initial diameter of about $46 \mathrm{~mm}$ is subjected to partial threshing at its very first impact with the rasp bars, which causes its diameter to decrease. As a result, a corn ear that enters a larger space is not effectively acted upon by the rasp bars and its movement rate may decrease, potentially subjecting the threshed grains to additional damage. These assumptions were verified in this work by experimental trials involving the analysis of corn ear movement using a high-speed video recording method that has been previously applied in similar studies $[7,10,15]$.

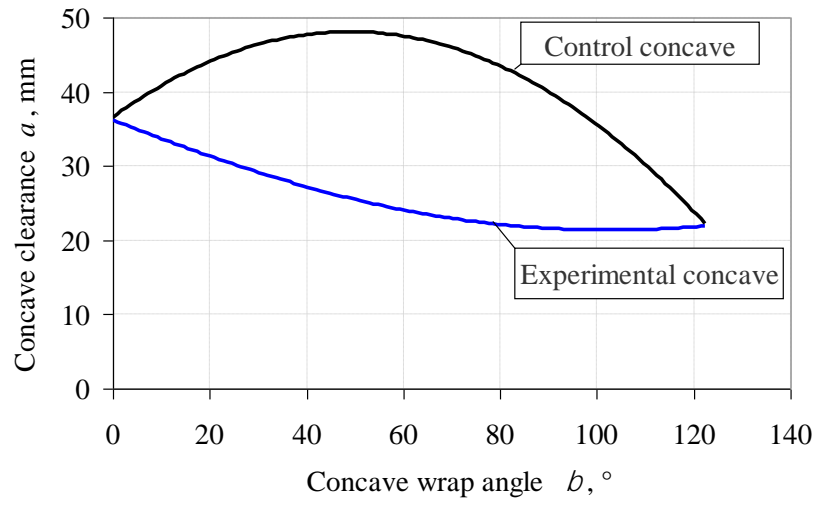

Fig. 5 Variation in clearance between cylinder rasp bars and concave crossbars

In a combine harvester, corn ears are fed into the threshing device by a scraper conveyor. Majority of the corn ears lie parallel to the cylinder shaft at the first concave crossbar. High-speed video analysis showed that the average corn ear movement rate was $6.12 \pm 0.99 \mathrm{~m} \mathrm{~s}^{-1}$ in the first third of the concave and $4.28 \pm 0.67 \mathrm{~m} \mathrm{~s}^{-1}$ in the middle of the concave (Table 3) during the threshing of single ears (with the threshing cylinder rotated at a rate of $350 \mathrm{~min}^{-1}$, and the clearance between the cylinder rasp bars and control concave rectangular crossbars set at $36-22 \mathrm{~mm}$ ) due to a considerable increase in the clearance between the cylinder rasp bars and concave crossbars (Fig. 5). The average corn ear movement rate in the clearance between the cylinder rasp bars and the concave was $4.76 \pm 0.48 \mathrm{~m} \mathrm{~s}^{-1}$. Each corn ear was subjected to nine or 10 contacts with the cylinder rasp bars. Where a moving ear, acted upon by rasp bar impacts, was rotated and became perpendicular to the concave crossbars, its movement rate decreased further in the middle section of the concave (to $2.20 \pm 0.44 \mathrm{~m} \mathrm{~s}^{-1}$ ). In this case, the average ear movement rate in the clearance between the cylinder rasp bars and concave was decreased to $3.78 \pm$ $0.29 \mathrm{~m} \mathrm{~s}^{-1}$. Each corn ear had about 10 contacts with the cylinder rasp bars; however, these contacts were inefficient in the middle section of the length, especially as the rasp bars often either only just touched, or did not touch, the top of the corn ear. Crossbar shape did not have any significant effect on corn ear movement rate, i.e. the trends referred to above were also found when using the concave with rounded crossbars (Table 3 ).

When corn ears entered the threshing device in a position perpendicular to the concave crossbar, they were subjected to impact, bending and slight forward pushing by the cylinder rasp bars. Corn ears were often broken into two halves, each of which moved randomly. On certain occasions, the onset of corn ear movement necessitated its pushing by a following ear. The movement of certain ear cobs with non-threshed grains in the middle of the concave (the section characterised by the largest clearance between the cylinder and concave) was decreased, or even stopped, as they did not contact the cylinder rasp bars. The average movement rate of corn ears moving perpendicular to the concave crossbars varied across a very wide range, and the corn ears had eight to 15 contacts with the cylinder rasp bars. The results of these trials support the arguments put forward in former studies; namely that (i) maximum grain damage is incurred by ears fed with their axis perpendicular to the cylinder axis [10], and (ii) corn ears that enter the threshing device orientated in this way move at half the speed and their cobs are broken into several parts, becoming threshed only if the clearance is reduced to $29-8 \mathrm{~mm}$ due to the greater number of impacts by the rasp bars [7].

Considering that the threshing device with the experimental concave demonstrated a uniform reduction in clearance between the cylinder and concave (Fig. 5), corn ears moving over the concave surface tended not to change their orientation with respect to the crossbars. The majority of corn ears moving towards the end of the concave lay parallel to the concave crossbars. Compared with the control concave, the corn ears moved at a more constant rate; the average rate in the first section of the concave was $6.04 \pm$ $0.47 \mathrm{~m} \mathrm{~s}^{-1}$, in the middle of the concave was $5.40 \pm$ $0.36 \mathrm{~m} \mathrm{~s}^{-1}$ and at the end of the concave was $5.02 \pm$ $0.42 \mathrm{~m} \mathrm{~s}^{-1}$ (Table 3). The average movement rate of corn ears $\left(5.48 \pm 0.25 \mathrm{~m} \mathrm{~s}^{-1}\right)$ was higher than the rate of corn ears moving over the control concave. Each corn ear had seven or eight contacts with the cylinder rasp bars, but these contacts were more effective than those of the control concave.

In general, it may be asserted that the trials on corn ear movement duration in separate sections of the concave (i.e. movement rate and number of impacts) have substantiated the need for further studies (e.g. studies on corn ear flow) as the corn ear movement rate in the second and third sections of the control concave arc length were shown to decrease considerably. This occurred despite a greater number of impacts because these impacts were inefficient. The experimental concave used for corn ear threshing may help to avoid the reduction in movement rate. In this case, it is likely that humid corn ears would be fully threshed more rapidly and the grain would be subjected to less damage. 
Indicators of corn ear movement in the threshing device with confidence interval

Table 3 values at $95 \%$ probability (clearance between crossbars $l=62.5 \mathrm{~mm}$ )

\begin{tabular}{|c|c|c|c|c|c|c|c|c|}
\hline \multirow{2}{*}{$\begin{array}{l}\text { Concave and } \\
\text { crossbar shape }\end{array}$} & \multicolumn{4}{|c|}{ Corn ear movement duration by concave sections $t, \mathrm{~s}$} & \multicolumn{4}{|c|}{ Corn ear movement rate $v, \mathrm{~m} \mathrm{~s}^{-1}$} \\
\hline & Section I & Section II & Section III & $\begin{array}{c}\text { Along entire } \\
\text { concave arc } \\
\text { length }\end{array}$ & Section I & Section II & Section III & $\begin{array}{l}\text { Along entire con } \\
\text { cave arc length }\end{array}$ \\
\hline $\begin{array}{l}\text { Rectangular: } \\
\text { control }\end{array}$ & $\begin{array}{c}0.058 \pm \\
0.010\end{array}$ & $\begin{array}{c}0.083 \pm \\
0.012\end{array}$ & $\begin{array}{c}0.088 \pm \\
0.014\end{array}$ & 0.229 & $6.12 \pm 0.99$ & $4.28 \pm 0.67$ & $4.05 \pm 0.60$ & $4.76 \pm 0.48$ \\
\hline experimental & $\begin{array}{c}0.056 \pm \\
0.003 \\
\end{array}$ & $\begin{array}{c}0.058 \pm \\
0.004 \\
\end{array}$ & $\begin{array}{c}0.067 \pm \\
0.005 \\
\end{array}$ & 0.181 & $6.04 \pm 0.47$ & $5.40 \pm 0.36$ & $5.02 \pm 0.42$ & $5.48 \pm 0.25$ \\
\hline $\begin{array}{l}\text { Rounded: } \\
\text { control }\end{array}$ & $\begin{array}{c}0.051 \pm \\
0.005\end{array}$ & $\begin{array}{c}0.076 \pm \\
0.010\end{array}$ & $\begin{array}{c}0.074 \pm \\
0.015\end{array}$ & 0.201 & $6.60 \pm 0.58$ & $4.46 \pm 0.72$ & $4.95 \pm 0.72$ & $4.86 \pm 0.41$ \\
\hline experimental & $\begin{array}{c}0.054 \pm \\
0.005 \\
\end{array}$ & $\begin{array}{c}0.058 \pm \\
0.004 \\
\end{array}$ & $\begin{array}{c}0.057 \pm \\
0.005 \\
\end{array}$ & 0.169 & $6.00 \pm 0.54$ & $5.62 \pm 0.46$ & $5.69 \pm 0.48$ & $5.77 \pm 0.27$ \\
\hline
\end{tabular}

\subsection{Grain threshing losses}

The corn ear feed rate is known to be one of the most important factors influencing the combine harvester's performance [27]. Correct threshing device adjustment is achieved when grains are removed from the cobs and the cobs are not broken [12]. In the present study, in the case of the control concave with the largest $(80.0 \mathrm{~mm})$ clearance between the crossbars (Fig. 6) and the corn ear flow into the threshing device increased from 5.6 to $20.6 \mathrm{~kg} \mathrm{~s}^{-1}$, the grain threshing loss increased from $0.6 \%$ to $3.0 \%$. For these values, the acceptable limit of grain threshing loss $(0.3 \%)$ was exceeded by 2 to 10 fold, respectively.

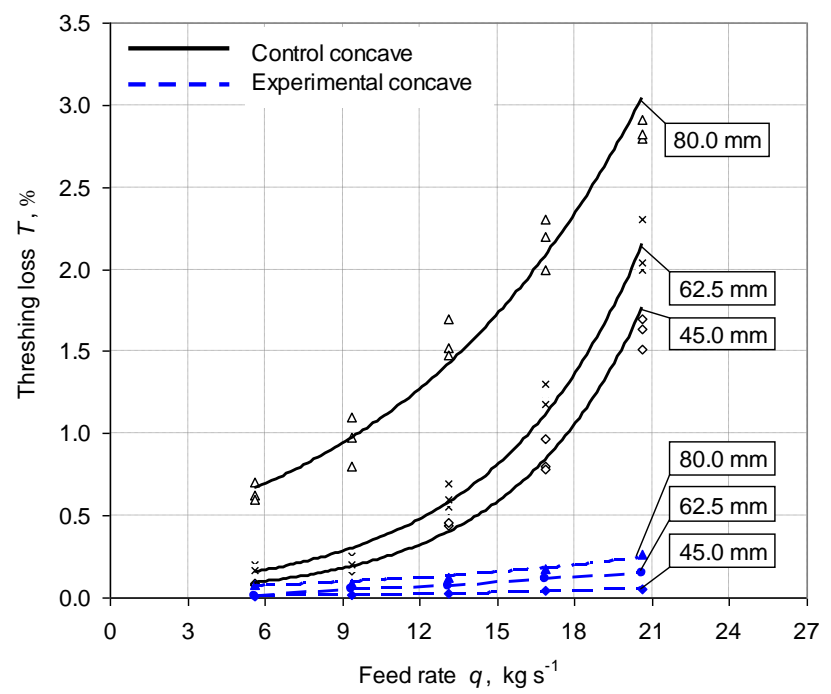

Fig. 6 Influence of concave shape and clearance between crossbars on grain threshing loss

It was noted that the largest portion of nonthreshed grains remained on the tips of broken ear cobs. Following the reduction of the clearance between the concave crossbars to $62.5 \mathrm{~mm}$ (the concave had 15 crossbars), grain threshing loss was reduced; however, it exceeded the acceptable loss at a corn ear feed rate above $10 \mathrm{~kg} \mathrm{~s}^{-1}$. Further reduction of the clearance to $45.0 \mathrm{~mm}$, i.e. an increase in the number of crossbars to 19 , did not yield a significant reduction in loss. In comparison, Norris and Wall [25] stated that eight concave crossbars are sufficient for full threshing of dry corn ears, but this requires increasing the height of the concave bars above the concave rods to $13 \mathrm{~mm}$. In the case of the experimental concave in the threshing device, grain threshing loss did not exceed the acceptable limit irrespective of the clearance between adjacent concave crossbars and of the corn ear feed rate.

In general, it can be asserted that the experimental concave helps reduce grain threshing loss below the acceptable limit even at a corn ear feed rate of $20 \mathrm{~kg} \mathrm{~s}^{-1}$. Moreover, reduction of the clearance between crossbars (from 80 to $45 \mathrm{~mm}$ ) in the control concave was found to have a considerably greater positive effect on grain threshing loss, as compared with the experimental concave.

\subsection{Loss of grain separation through concave}

One of the key performance indicators of the corn ear threshing process is grain separation loss, i.e. grain that has been threshed but not passed the concave. Petkevichius et al. [7] stated that with correct adjustment of the threshing apparatus, separation loss should not exceed $20 \%$ of the grain feed rate. Grain separation loss in the threshing device is known to be considerably reduced by increasing the concave length, i.e. the separation area [28, 29]. The present study has determined that concave shape does influence grain separation loss. In the case of the control concave (conventional design), with the ear feed rate $q$ increased from 5.6 to $20.6 \mathrm{~kg} \mathrm{~s}^{-1}, 15.1 \%$ to $23.3 \%$ of the grains reached the straw walkers, respectively, whereas in the case of experimental concave, $4.7 \%$ to $12.6 \%$ of the grains reached the straw walkers, respectively. Separation of the threshed grain through the concave grating can be increased two-fold (on average) using the experimental concave (Fig. 7). Moreover, the concave shape has been found to have no significant influence on the cleanness of grain falling through the concave (Table 4).

An increase in the clearance between the crossbars (from 45 to $80 \mathrm{~mm}$ ) influenced grain separation through the control concave only and only for corn ear feed rates above $12 \mathrm{~kg} \mathrm{~s}^{-1}$.

In general, it can be asserted that adjustment of concave shape may considerably reduce portion of grain threshed that ends up on the straw walkers, i.e. the separation loss. Moreover, concave shape does not have a significant influence on the cleanness of grains passing through the grating of the concave. 
Effect of concave shape on the proportion of impurities $P$ in the mass separated

Table 4 through the concave with confidence interval values at $95 \%$ probability

\begin{tabular}{|c|c|c|c|c|}
\hline Concave & $\begin{array}{c}\text { Clearance between } \\
\text { crossbars } l, \mathrm{~mm}\end{array}$ & $\begin{array}{c}\text { Section I of the } \\
\text { concave } P_{1}, \mathrm{~g}\end{array}$ & $\begin{array}{c}\text { Section II of the } \\
\text { concave } P_{2}, \mathrm{~g}\end{array}$ & $\begin{array}{c}\text { Section III of the } \\
\text { concave } P_{3}, \mathrm{~g}\end{array}$ \\
\hline \multirow{3}{*}{ Experimental } & 45.0 & $1.18 \pm 0.35$ & $1.36 \pm 0.28$ & $1.61 \pm 0.36$ \\
\cline { 2 - 5 } & 62.5 & $1.62 \pm 0.36$ & $1.69 \pm 0.44$ & $1.76 \pm 0.34$ \\
\cline { 2 - 5 } & 80.0 & $1.98 \pm 0.25$ & $2.26 \pm 0.39$ & $2.41 \pm 0.32$ \\
\hline \multirow{3}{*}{ Control } & 45.0 & $1.04 \pm 0.57$ & $1.49 \pm 0.42$ & $2.32 \pm 0.66$ \\
\cline { 2 - 5 } & 62.5 & $1.34 \pm 0.17$ & $1.61 \pm 0.21$ & $2.48 \pm 0.58$ \\
\cline { 2 - 5 } & 80.0 & $1.79 \pm 0.23$ & $1.92 \pm 0.20$ & $3.05 \pm 0.69$ \\
\hline
\end{tabular}

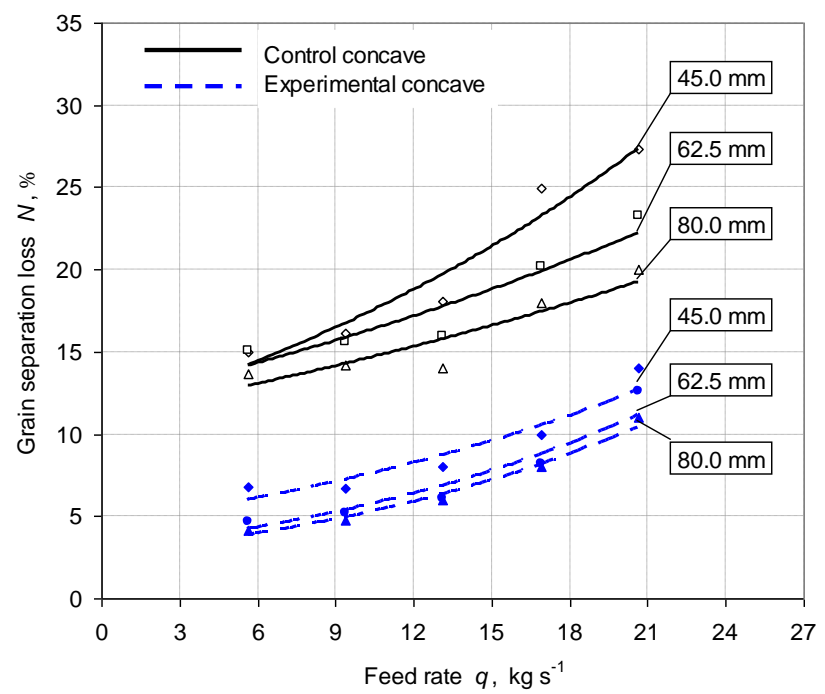

Fig. 7 Influence of concave shape and clearance between crossbars on separation loss through the concave (each point on the graph is the arithmetic average of three replications)

\subsection{Grain damage}

Excessive threshing has been reported to result in low threshing losses and greater grain damage $[12,30]$. Experimental results by a number of researchers indicated that the moisture content of grain has a significant influence on grain breakage [7, 10, 17, 30, 31].

The portion of grain subjected to damage was consistently reduced with an increase in corn ear feed rate from 5.6 to $20.6 \mathrm{~kg} \mathrm{~s}^{-1}$ for both the control and experimental concaves (Fig. 8). Nevertheless, more grains were subjected to damage in the threshing device with the control concave. This was influenced by variations in corn ear movement rate, the number of contacts between the corn ears and rasp bars and the clearance between the cylinder rasp bars and concave crossbars. For the threshing device with the control concave, the clearance between the crossbars and cylinder rasp bars initially increased, before decreasing. On the other hand, for the experimental concave, the clearance consistently decreased along the concave length. As a result, the number of contacts between the cylinder rasp bars and corn ears was twice as high in the threshing device with the control concave.

An increase from 45.0 to $62.5 \mathrm{~mm}$ in the clearance between the crossbars in the experimental concave resulted in an average grain damage that did not exceed the acceptable limit of 3\% (Fig. 8). However, in the control concave, only at a corn ear feed rate of $20.6 \mathrm{~kg} \mathrm{~s}^{-1}$ was the acceptable loss not exceeded. In both concaves, the acceptable limit of damaged grain was not exceeded upon increase of the clearance between the crossbars to $80 \mathrm{~mm}$, irrespective of the corn ear feed rate.

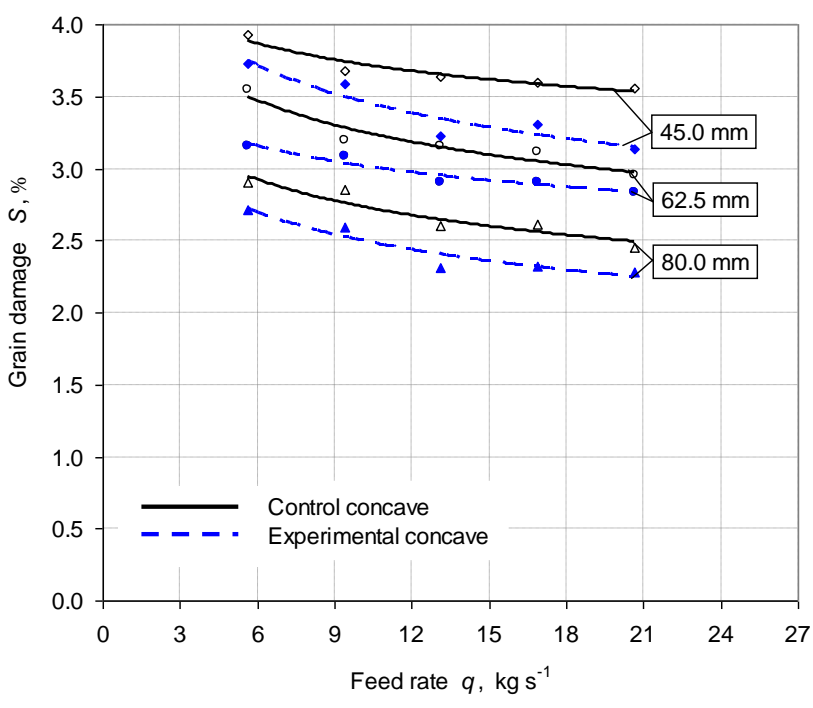

Fig. 8 Influence of concave shape and clearance between crossbars on grain damage (each point in the graph is the arithmetic average of three replications)

The consistency of the corn ear threshing process is characterised by grain separation variation along the concave length [20]. In the present study, variation in grain separation through sections of the control and experimental concaves was compared by adjusting the corn ear feed rate into the threshing device at a $62.5 \mathrm{~mm}$ clearance between the concave crossbars. At a corn ear feed rate into the threshing device of $20.6 \mathrm{~kg} \mathrm{~s}^{-1}, 35.23 \% \pm 1.53 \%$ of the grain fell through the first section of the control concave, and $42.13 \%$ $\pm 2.29 \%$ fell through the first section of the experimental concave (Fig. 9). The difference was even at lower corn ear feed rates. Grain separation through the entire control concave was significantly faster and amounted to $72 \%$ of the grain, whereas through the experimental concave, it was $87 \%$ of the grain. The intensification of separation, particularly in the first section, reduced grain damage for the experimental concave (Fig. 8). This supports the argument generated by earlier studies; namely that grain damage can potentially be reduced when the shelled grains are expelled from the threshing crescent immediately after threshing [23]. 


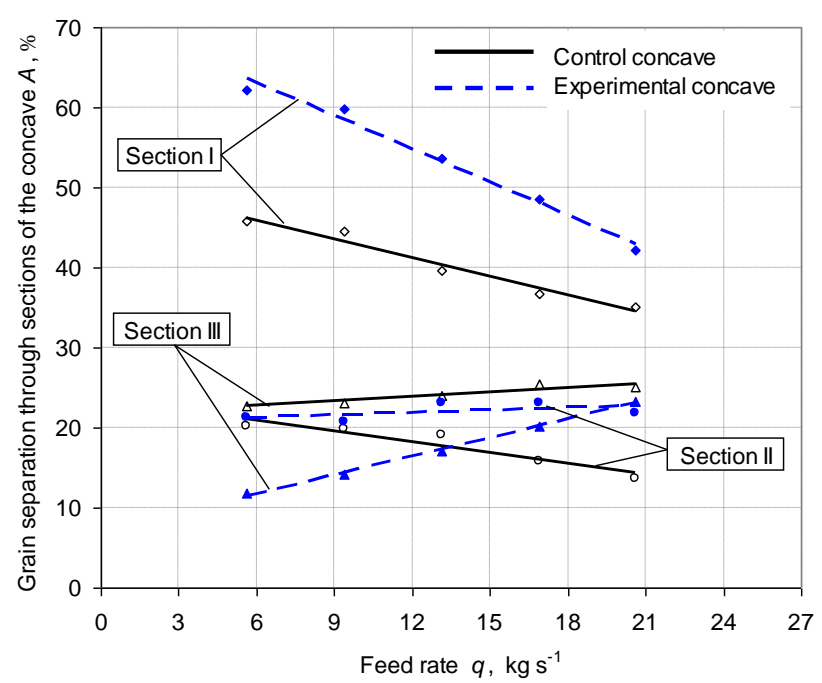

Fig. 9 Influence of concave shape on separation of grain by sections of the experimental concave, where $l=$ $62.5 \mathrm{~mm}$ (each point in the graph is the arithmetic average of three replications)
The study results support the use of a rational $62.5 \mathrm{~mm}$ clearance between the crossbars in the experimental concave, ensuring that the portion of damaged grain does not exceed the acceptable limit of 3\%. Grain damage showed a downward trend with increasing corn ear feed rate. In general, it could be asserted that a considerable increase in grain separation in the first section of the experimental concave is a key factor in grain damage reduction.

\subsection{Power consumption}

Some studies have already determined that corn ear feed rate influences power, and in turn fuel consumption $[24,32]$. This study aimed to determine the additional power requirement of corn ear threshing after replacement of the control concave with the experimental concave. Our results demonstrated that in view of the shape of the experimental concave, about $2 \mathrm{~kW}$ of additional power is required, irrespective of the corn ear feed rate (Fig. 10a). It was also determined that an increase in the clearance between the crossbars from 45.0 to $80.0 \mathrm{~mm}$ leads to only a minor reduction in the need for power (by about $0.5 \mathrm{~kW}$ ) (Fig. 10b).

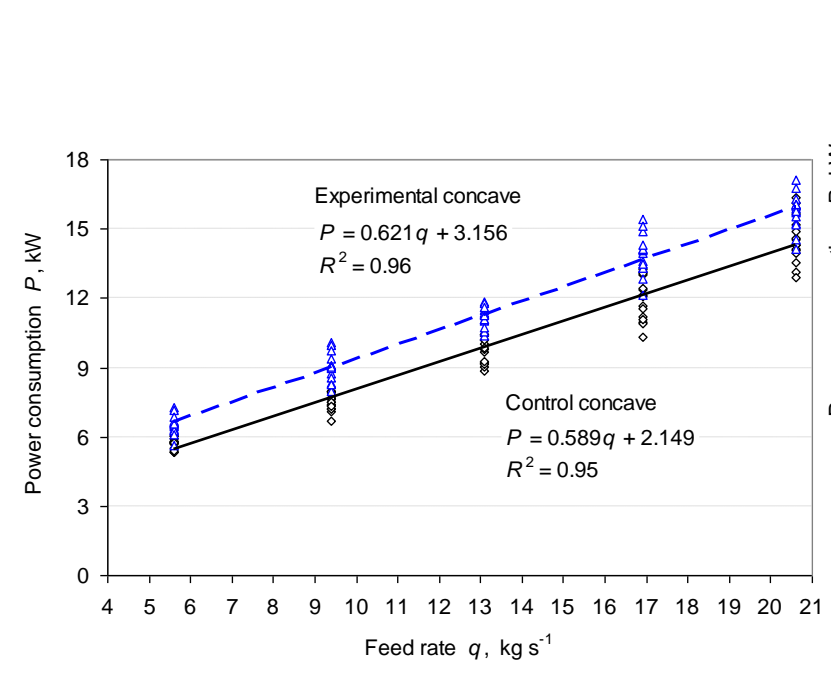

a

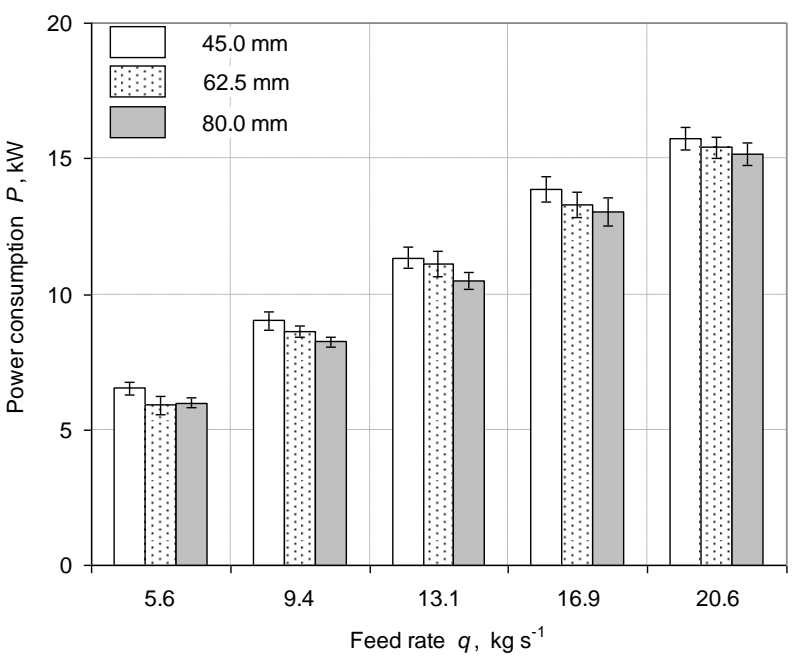

$\mathrm{b}$

Fig. 10 Dependence of power requirement on (a) the concave shape with a $62.5-\mathrm{mm}$ clearance and (b) clearance between the crossbars of the experimental concave

The detachment of grains from corn ears is accomplished by a combination of impacts and a rubbing action [14]. Impact loads are known to cause more damage to grain than the rubbing action $[2,17]$. This is supported by the fact that axial threshing devices cause less grain damage [2]. It would therefore be reasonable for further studies to focus on the installation of diagonal crossbars in the validated experimental concave [18] to ensure that a rubbing action, rather than an impact action, prevails during threshing.

\section{Conclusions}

1. In the case of correspondence between the control concave surface line and a circular arc, the clearance between the crossbars and cylinder rasp bars from the beginning of the concave to a wrap angle of $\beta=45^{\circ}$ increased from 36 to $48 \mathrm{~mm}$, before decreasing to $22 \mathrm{~mm}$. In the case of correspondence between the experimental concave surface line with a portion of Archimedes' spiral, the clearance along the entire length of the concave was reduced from 36 to $22 \mathrm{~mm}$. The difference between these designs controlled the difference in the rate of corn ear movement over the concave surfaces. Corn ear movement rate was subjected to considerable reduction in the second and third sections of the control concave length despite a greater number of impacts, because these impacts were ineffective. A significant rate reduction could be avoided if the experimental concave was used for corn ear threshing.

The average movement rate of a corn ears, entered the threshing device in a position parallel to the concave crossbar, over the control concave surface was $4.76 \pm$ $0.48 \mathrm{~m} \mathrm{~s}^{-1}$ and the corn ear had nine or 10 contacts with the cylinder rasp bars. For the experimental concave, the corn ear average movement rate was $5.48 \pm 0.25 \mathrm{~m} \mathrm{~s}^{-1}$, with seven or eight contacts between the corn ear and the cylinder rasp bars.

2. During the threshing of high moisture (grain moisture content of $36.16 \% \pm 1.83 \%$ ) corn ears, with the clearance between the control concave crossbars $l$ set to $62.5 \mathrm{~mm}$, the grain threshing loss amounted to $2.2 \%$ (where 
$q=20.6 \mathrm{~kg} \mathrm{~s}^{-1}$ ). This loss increased to $2.8 \%$ upon an increase of $l$. For the experimental concave, the dependence of the loss on $q$ and $l$ was insignificant and the loss did not exceed the acceptable limit of $0.3 \%$.

3 . The experimental concave enabled about a twofold increase in threshed grain separation through the concave grating. For the experimental concave, the intensification of separation, particularly in the first section, allowed for a reduction in grain damage of about 0.5 of percentage point in case of the experimental concave. In view of the results on grain damage and separation, a rational $62.5 \mathrm{~mm}$ clearance between the crossbars of the experimental concave has been validated, i.e. the portion of damaged grain did not exceed the acceptable limit of $3 \%$ at that point. Grain damaged showed a downward trend with increasing corn ear feed rate.

4. The shape of the experimental concave resulted in an increased power requirement of about $2 \mathrm{~kW}$ compared with the control concave, irrespective of the corn ear feed rate $\left(q=5.4-20.6 \mathrm{~kg} \mathrm{~s}^{-1}\right)$. Moreover, an increase in clearance between the experimental concave crossbars from 45.0 to $80.0 \mathrm{~mm}$ was found to yield only a minor reduction in the need for power (by about $0.5 \mathrm{~kW}$ ).

\section{References}

1. Yang, L.; Cui, T.; Qu, Z.; Li, K.; Yin, X.; Han, D.; Yan, B.; Zhao, D.; Zhang, D. 2016. Development and application of mechanized maize harvesters, International Journal of Agricultural and Biological Engineering 9(3): 15-28. http://dx.doi.org/10.3965/j.ijabe.20160903.2380.

2. Wacker, P. 2005. Maize grain damage during harvest, Landtechnik 60(2): 84-85.

3. Miu P.I. 2015. Cereal threshing and separating processes: threshing units. In: Miu, P. (ed.) Theory, Modelling, and Design. CRC Press: 189-260.

http://dx.doi.org/10.1201/b18852-6.

4. Poničan, J.; Angelovič, M.; Jech, J.; Žitňák, M.; Findura, P. 2009. The effect of the design concept of combine harvester threshing mechanism on the maize crop threshing quality, Contemporary Agricultural Engineering 35(4): 268-274.

5. Mümken, P.; Baumgarten, J.; Böttinger, S. 2012. Basics for tangential threshing devices - mathematical description of the curve characteristic of the concave clearance, Landtechnik 67(1): 26-30.

6. Huang, H., Faulkner, D. B., Berger, L. L., Eckhoff, S. R. 2012. Harvest date influence on dry matter yield and moisture of corn and stover, Transactions of the ASABE 55(2): 593-598. https://doi.org/10.13031/2013.41360.

7. Petkevichius, S.; Shpokas, L.; Kutzbach, H.D. 2008. Investigation of the maize ear threshing process, Biosystems Engineering 99: 532-539. http://dx.doi.org/10.1016/j.biosystemseng.2008.01.002.

8. Ferreira, V. F.; Oliveira, J. A.; Ferreira, T. F.; Reis, L. V.; de Andrade, V.; Neto, J. C. 2013. Quality of maize seeds harvested and husked at high moisture levels, Journal of Seed Science 35(3): 276-277. https://doi.org/10.1590/S2317-15372013000300001.

9. Baktash, F.Y.; Alkazaali, H.A. 2016. Effect of grain moisture of corn at harvesting on some agronomic traits,
The Iraqi Journal of Agricultural Sciences 47(5): 13341339.

10. Mahmoud, A.R.; Buchele, W.F. 1975. Corn ear orientation effects on mechanical damage and forces on concave, Transactions of the ASAE 18(3): 444-452. https://doi.org/10.13031/2013.36607.

11. Kutzbach, H.-D.; Quick, G.R. 1999. Grain Harvesters and Threshers. In: Stout, B.A.; Cheze, B. Plant Production Engineering: CIGR Handbook of Agricultural Engineering. Vol. III. American Society of Agricultural Engineers. St. Joseph, Michigan. pp. 311-347.

12. Humberg, D.S.; Nicolai, R.E.; Reitsma, K.D. 2009. Corn grain harvest. In: Clay, D.E.; Reitsma, K.D.; Clay, S.A. (eds.), Best Management Practices for Corn Production in South Dakota. EC929, South Dakota State University, South Dakota Cooperative Extension Service, Brookings, SD, p.p. 93-98. http://openprairie.sdstate.edu/extension_circ/501.

13. Paulsen, M.R.; Pinto, F.A.C.; de Sena Jr., D.G.; Zandonadi, R.S.; Ruffato, S.; Gomide Costa, A.; Ragagnin, V.A.; Danao, M.-G.C. 2014. Measurement of combine losses for corn and soybeans in Brazil, Applied Engineering in Agriculture 30(6): 841-855. http://dx.doi.org/10.13031/aea.30.10360.

14. Miodragovic, R.; Djevic, M. 2006. Contemporary combine harvesters in corn harvesting, Annals of the Faculty of Engineering Hunedoara 4(3): 199-206.

15. Brandini, A. 1969. Corn kernel forces during impact shelling. Retrospective Theses and Dissertations. Paper 14482. Iowa State University, Ames, Iowa. 87 p.

16. Vindizhev, N.L. 1996. Theoretical Basis of Corn Ears Threshing. Materials of Scientific-Practical Conference Kabardino-Balkarian State Agricultural Academy, Nalchik. pp. 14-18 (in Russian).

17. Kustermann, M. 1987. Impact load of corn kernel, Grundlagen der Landtechnik 37(4): 121-131 (in German).

18. Pužauskas, E.; Steponavičius, D.; Jotautienė, E.; Petkevičius, S.; Kemzūraitè, A. 2016. Substantiation of concave crossbars shape for corn ears threshing, Mechanika 22(6): 553-561. http://dx.doi.org/10.5755/j01.mech.22.6.16370.

19. Poničan, J.; Angelovič, M.; Jech, J.; Žitnak, M. 2007. Effects of kinematic parameters of combine harvester on maize grain quality, Contemporary Agricultural Engineering 33(3-4): 135-142.

20. Kravchenko, V.S. 1984 . The radius of the concave of threshing apparatus for corn ears threshing, Mechanization and Electrification of Agriculture 9: 26-29 (in Russian).

21. Kravchenko, V.S.; Kutseev, V.V. 1987. The quality of corn ears threshing in depending on the constructive features of threshing devices, The Bulletin of Agricultural Science. Moscow 1: 94-99 (in Russian).

22. Svoboda, J.; Prochazka, B.; Piszczalka, J. 1990. The effect of the cylinder-concave clearance on the quality of maize shelling, Zemedelska Technika 36(6): 343-351.

23. Chowdhury, M.H.; Buchele, W.F. 1978. The nature of corn kernel damage inflicted in the shelling crescent of grain combines, Transactions of the ASAE 21(4): 610614.

https://doi.org/10.13031/2013.35353.

24. Srison, W.; Chuan-Udom, S.; Saengprachatanarug, K. 2015. Design factors affecting losses of an axial flow 
corn shelling unit. The $8^{\text {th }}$ TSAE international conference. Bangkok, Thailand. pp. 256-260.

25. Norris, E.R.; Wall, G.L. 1986. Effect of concave design factors on cylinder-concave performance in corn, Canadian Agricultural Engineering 28(2): 97-99.

26. Brusentsov, A.S. 2009. The parameters of the threshing device of a combine harvester for harvesting legumes seeds, Abstract doctor diss, Krasnodar: Kuban State Agrarian University. 24 p. (in Russian).

27. Yu, Y.; Fu, H.; Yu, J. 2015. DEM-based simulation of the corn threshing process, Advanced Powder Technology 26: 1400-1409. http://dx.doi.org/10.1016/j.apt.2015.07.015.

28. Nguyen, X.T.; Bernhardt, G.; Herlitzius, T. 2008. Influence of concave length and feeding angle on separation capacity in the multi-cylinder threshing system, Landtechnik 63(5): 276-277.

29. Miu, P.I.; Kutzbach, H.-D. 2008. Modeling and simulation of grain threshing and separation in threshing units-Part I, Computers and Electronics in Agriculture 60(1): 96-104. https://doi.org/10.1016/j.compag.2007.07.003.

30. Quick, G.R. 2003. Combine sweet spot: integrating harvested yield, grain damage and losses, Proceedings of the International Conference on Crop Harvesting and Processing, 9-11 February 2003, American Society of Agricultural and Biological Engineers. Louisville, Kentucky, p. 63. 701P1103e. https://doi:10.13031/2013.15211.

31. Srison, W.; Chuan-Udom, S.; Saengprachatanarak, K. 2016. Effects of operating factors for an axial-flow corn shelling unit on losses and power consumption, Agriculture and Natural Resources 50: 421-425. http://dx.doi.org/10.1016/j.anres.2016.05.002.

32. Pishgar-Komleh, S.H.; $\quad$ Keyhani, A.; MostofiSarkari, M.R.; Jafari, A. 2013. Assessment and determination of seed corn combine harvesting losses and energy consumption, Elixir Agriculture 54: 12631-12637.
D. Steponavičius, E. Pužauskas, L. Špokas, E. Jotautienė, A. Kemzūraitè, S. Petkevičius

\section{CONCAVE DESIGN FOR HIGH-MOISTURE CORN EAR THRESHING}

S u m m a r y

In a threshing device, identifying the optimum balance between grain damage and grain loss during threshing is highly relevant while harvesting high-moisture corn ears. The qualitative performance indicators of a threshing device depend on the corn ear properties and process parameters as well as the device's design. Comparative experimental trials of two concaves (control and experimental) of a tangential threshing device were conducted under laboratory conditions by threshing high-moisture corn ears. The control concave's surface line corresponded to a circular arc, whereas that of the experimental concave corresponded to a portion of Archimedes' spiral. The clearance between the crossbars and cylinder rasp bars in the first section of the control concave length increased, whereas in the second section, it decreased. For the experimental concave, the clearance along the entire concave length consistently decreased. The experimental concave yielded approximately half the grain loss of the control during separation in the concave. A rational clearance between the experimental concave crossbars was validated because the portion of damaged grain did not exceed $3 \%$ at that point. With clearance $l$ equal to $62.5 \mathrm{~mm}$ in the control concave, the grain threshing loss was $2.2 \%$, whereas for the experimental concave, the loss was virtually independent of $q$ and did not exceed the acceptable $0.3 \%$ limit. In general, the trials demonstrated that for high-moisture corn ear threshing, the surface line of the concave should correspond to a portion of Archimedes' spiral and the clearances between adjacent crossbars should be $62.5 \mathrm{~mm}$.

Keywords: tangential threshing device, ear feed rate, grain separation, grain damage, power consumption.

Received June 09, 2017

Accepted February 15, 2018 